\title{
Vascular injury in spontaneous subacute toxicosis caused by organic arsenic in cattle ${ }^{1}$
}

\author{
Maiara A. Gonçalves ${ }^{2 *}$, Raquel A.S. da Cruz², Matheus O. Reis², Saulo P. Pavarini², \\ Luciana Sonne ${ }^{2}$ and David Driemeier ${ }^{2}$
}

\begin{abstract}
Gonçalves M.A., Cruz R.A.S., Reis M.O., Pavarini S.P., Sonne L. \& Driemeier D. 2017. Vascular injury in spontaneous subacute toxicosis caused by organic arsenic in cattle. Pesquisa Veterinária Brasileira 37(7):676-680. Setor de Patologia Veterinária, Faculdade de Veterinária, Universidade Federal do Rio Grande do Sul, Av. Bento Gonçalves 9090, Porto Alegre, RS 91540-000, Brazil. E-mail: davetpat@ufrgs.br

Monosodium methanearsonate (MSMA) is an organic form of arsenic present in the formulations of some herbicides. Accidental ingestion of pasture contaminated with arsenic may lead to toxicosis in cattle. Almost 200 head of cattle maintained in an area sprayed with MSMA presented with intense diarrhea and dehydration after grazing. Subsequently, 16 of these animals died. Toxic levels of arsenic $(>1.5 \mu \mathrm{g} / \mathrm{g})$ were detected in the kidney, liver, urine, and skeletal muscle of 6 animals. At gross inspection were observed multifocal to coalescent ulcers in the mucosa from on the forestomachs associated with hemorrhagic areas and marked wall edema. Microscopic examination mainly showed fibrinoid necrosis of vessels with multifocal thrombosis associated with ischemic infarction that were characterized by large transmural necrotic areas in the forestomachs. The clinical and pathological changes interestingly showed that this form of arsenic although considered less toxic, has caused severe vascular injury in forestomachs of cattle.
\end{abstract}

INDEX TERMS: Toxicosis, organic arsenic, cattle, MSMA, arsenic poisoning, vascular necrosis.

RESUMO.- [Injúria vascular na toxicose subaguda espontânea causada por arsênio orgânico em bovinos.] Metano-arseniato ácido monossódico (MSMA) é uma forma orgânica de arsênio, presente nas formulações de alguns herbicidas. A ingestão acidental de pasto contaminado por arsênio pode levar a toxicose em bovinos. Aproximadamente 200 bovinos que estavam em uma pastagem pulverizada com MSMA manifestaram intensa diarreia e desidratação após o pastejo. Subsequentemente, 16 animais morreram. Níveis tóxicos de arsênio $(>1.5 \mu \mathrm{g} / \mathrm{g})$ foram detectados no rim, fígado, urina e músculo esquelético de 6 animais. A inspeção macroscópica revelou úlceras multifocais a coalescentes na mucosa de pré-estômagos, adjacentes a focos de hemorragia e intenso edema de parede. A avaliação microscópica revelou, predominantemente, necrose fibrinoide de vasos com trombose multifocal associada a infarto,

\footnotetext{
${ }^{1}$ Received on September 21, 2016.

Accepted for publication on November 21, 2016.

${ }^{2}$ Setor de Patologia Veterinária, Faculdade de Veterinária, Universidade Federal do Rio Grande do Sul (UFRGS), Av. Bento Gonçalves 9090, Porto Alegre, RS 91540-000, Brazil. *Corresponding author: maiaragoncalvesrs@ hotmail.com
}

caracterizado por grandes áreas de necrose transmural em pré-estômagos. As alterações clínicas e patológicas, interessantemente, demonstraram que esta forma de arsênio, apesar de ser considerada menos tóxica, causou severa injúria vascular em pré-estômagos de bovinos.

TERMOS DE INDEXAÇÃO: Toxicose, arsênio orgânico, bovinos, MSMA, intoxicação por organoarsênio, necrose vascular.

\section{INTRODUCTION}

Arsenic (As) is one of the chemical elements that is usually described as a metalloid or semimetal and occurs in both organic and inorganic forms in its trivalent ( $\left.A \mathrm{~s}^{\mathrm{III}}\right)$ or pentavalent $\left(A s^{V}\right.$ ) oxidation states (ATSDR 2015). Several studies in the past have described toxicosis caused by As in cattle, mostly due to grazing on contaminated pasture by the inorganic form, especially until the 1990s prior to the ban on its use in agrochemicals (Hatch \& Funnell 1969, Nelson et al. 1971, Reviere et al. 1981, Monies 1999, Neiger et al. 2004, Valentine et al. 2007). The toxicosis caused by organic As compounds has also been reported, typically due to the use of growth promoter additive containing As in the animal feed (Vorhies et al. 1969). In addition, an outbreak 
described in cattle was caused by cupric acetoarsenite, an organic As ${ }^{\mathrm{III}}$ compound (Neiger et al. 2004). Monosodium methanearsonate (MSMA) is too an organic $\mathrm{As}^{\mathrm{V}}$, present in herbicide formulations that are used in several countries (Serodio 2014). However, despite widespread use, the only report on accidental toxicosis of cattle with MSMA was a recent investigation (Dantas et al. 2012). An experimental challenge using the compound was too described in a pioneering study (Dickinson 1972).

Ulcerative and erosive lesions on the gastric mucosa and submucosal edema have been observed in inorganic and organic As poisoning (Dickinson 1972, Faires 2004, Neiger et al. 2004, Valentine et al. 2007, Dantas et al. 2012, Bertin et al. 2013). The toxicodynamics of As in both its forms seems to be similar and vascular changes are implicated as a factor that contributes to the hemorrhagic, degenerative and necrotic lesions observed by many authors (Döbereiner et al. 1967, Monies 1999, Dantas et al. 2012, Bertin et al. 2013). However, injuries related to vascular necrosis are not mentioned in prior reports in cattle.

The present study describes the clinical and pathological aspects of one spontaneous, subacute outbreak of toxicosis due to MSMA, a type of organic As, in beef cattle.

\section{MATERIALS AND METHODS}

A technical visit was carried out in a farm in south of Rio Grande do Sul. The main complaint was ingestion of pasture sprayed with an herbicide containing MSMA by a herd of 200 beef cattle. The clinical condition of the animals was accompanied, as well as, carried out epidemiological investigation in the period.

Two animals (bovines A and B) were necropsied 4 days after a first exposure to MSMA (on the 4 th $^{\mathrm{h}}$ day), 3 on the $6^{\text {th }}$ day (bovines C, D, and E) and one on the $10^{\text {th }}$ day (bovine F). Histological analysis was carried out using various tissue samples that had been fixed in $10 \%$ formalin, embedded in paraffin, and cut into $3-\mu$ m-thick sections that were subsequently stained using hematoxylin-eosin (HE) protocol, periodic acid-Schiff (PAS) and Grocott's methenamine silver (GMS). The levels of As in the liver, kidney, skeletal muscle, and urine, as well as in pasture samples collected at different time points, were determined using hydride generation-atomic absorption spectroscopy, adjusted for As at $193.7 \mathrm{~mm}$ with a detection limit set at $0.5 \mathrm{ppm}(\mu \mathrm{g} / \mathrm{mL}$ or $\mu \mathrm{g} / \mathrm{g})$.

\section{RESULTS}

Approximately 200 cows and heifers bred in a farm in south of Rio Grande do Sul accidentally ingested pasture contaminated with an herbicide containing MSMA. The herbicide was sprayed on the pasture twice over a 5-day period as a means to control South African annoni (Eragrostis plana), a fiber-rich, invasive pasture species in the region. As early as a few hours after the first application of the herbicide, the majority of the animals presented diarrhea of various degrees of consistency, in addition to anorexia, pale mucosae, and severe dehydration. The first deaths occurred on

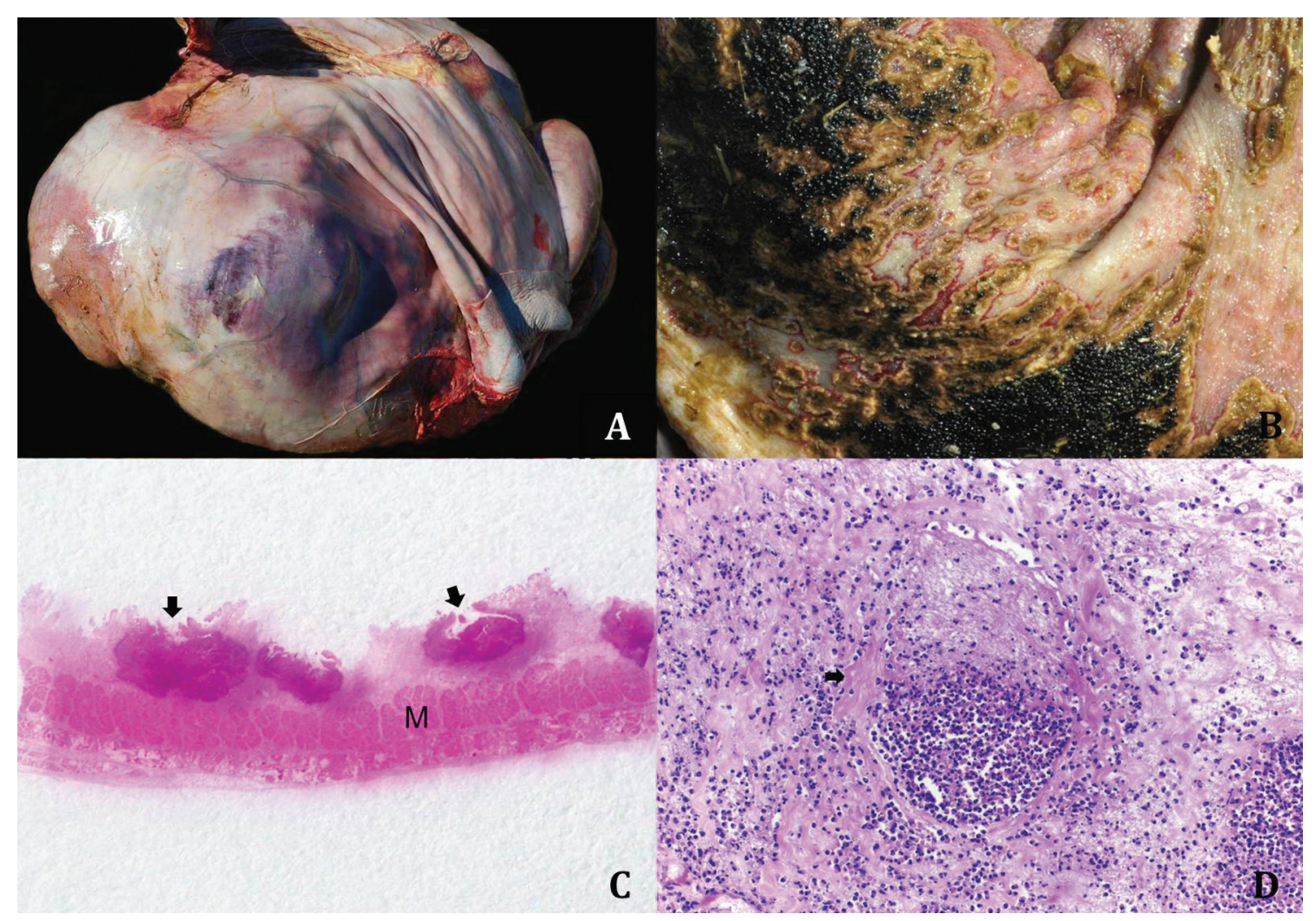

Fig.1. (A) Bovine forestomachs with focally extensive infarction of the ruminal wall, characterized by intense transmural red area visible from the serosa. (B) Bovine rumen with multifocal to coalescing 0.5-cm ulcers on the mucosa; the ulcers are covered with yellow material (diphtheritic membrane) and outlined by distinct red rim and focal detachment from the surrounding mucosa. (C) Bovine rumen with multifocal transmural infarctions (arrow) from the mucosa to the outer muscle layer (M). HE, obj.2.5x. (D) Bovine rumen submucosa showing a blood vessel with fibrinoid necrosis of the wall (arrow) and thrombosis. HE, obj.20x. 273x190mm (150 x 150 DPI). 
the $4^{\text {th }}$ day. Five days after the first application, the pasture received another round of treatment with the same herbicide, and the animals' clinical condition worsened. All the herd was then taken to another pasture that was free of herbicide. In total, after removing, 16 bovines died within 20 days, of which 12 died within 10 days of the first herbicide application.

Necropsy revealed undigested contents filling the rumen, which exhibited diffusely reddened mucosa and focally extensive reddened areas in the serosa of the forestomachs (6/6) (Fig.1A). In bovine F, the rumen mucosa showed large multifocal to coalescent ulcers covered with yellowish material that were depressed in the middle, and were outlined with reddish edges, also, often detachment from the surrounding mucosa (Fig.1B). Additionally, the forestomachs and abomasum exhibited considerably thickened submucosa associated with edema and multifocal hemorrhage (6/6), mainly in the reticulum and omasum. Diffuse reddening was observed on the medullar region of the kidneys (6/6). Furthermore, diffuse congestion and occasional petechiae were detected in both the large and small intestines $(6 / 6)$. No significant gross changes were observed in the other organs.

Microscopically there was necrosis primarily in the capillaries and arterioles of the rumen mucosa and submucosa, as well as in the reticulum and omasum (Fig.1C), associated to intense vasculitis with mural infiltration of degenerate neutrophils. Additionally, congestion and intense diffuse edema were noticed $(6 / 6)$. Blood vessels exhibited fibrinoid necrosis of the wall with moderate to intense hyaline build-up, as well as accumulation of fibrillary material, erythrocytes, and leukocytes in the lumen (thrombus) (Fig.1D). These areas also showed abundant fibrin exudate, hemorrhage, and occasional perivascular inflammatory infiltration of macrophages and both degenerate and non-degenerate neutrophils associated with multifocal transmural necrosis in mucosa and submucosa, often affecting the outer muscle layer (areas of infarction). More conspicuous fibrinoid necrosis of the vessels and infarcted areas was detected in bovines $C, D$, and $F(3 / 6)$, particularly larger areas of infarction in bovine F. Kidney tissue showed mild to intense medullary congestion (6/6). Table 1 shows the As levels detected in the tissue samples, urine, and pasture, at different time points.

Table 1. Total arsenic levels, analyzed at three different time points, in tissue and urine samples of necropsied cattle and in the pasture

\begin{tabular}{|c|c|c|c|c|c|c|c|}
\hline \multirow{2}{*}{$\begin{array}{l}\text { Material } \\
\text { collected }\end{array}$} & \multirow{2}{*}{$\begin{array}{c}\text { Detection } \\
\text { unit }\end{array}$} & \multicolumn{2}{|c|}{ 4th day } & \multicolumn{2}{|c|}{ 6th day } & \multicolumn{2}{|c|}{ 10th day } \\
\hline & & $\begin{array}{c}\text { Bovine } \\
\text { A }\end{array}$ & $\begin{array}{c}\text { Bovine } \\
\text { B }\end{array}$ & $\begin{array}{c}\text { Bovine } \\
\text { C }\end{array}$ & $\begin{array}{c}\text { Bovine } \\
\text { D }\end{array}$ & $\begin{array}{c}\text { Bovine } \\
\text { E }\end{array}$ & $\begin{array}{c}\text { Bovine } \\
\text { F }\end{array}$ \\
\hline Liver & $\mu \mathrm{g} / \mathrm{g}$ & 5.5 & 2.2 & 16.0 & 1.5 & $\mathrm{a}$ & $<0.5 b$ \\
\hline Kidney & $\mu \mathrm{g} / \mathrm{g}$ & 4.6 & 3.3 & 7.2 & 2.8 & $\mathrm{a}$ & $<0.5 b$ \\
\hline $\begin{array}{l}\text { Skeletal } \\
\text { muscle }\end{array}$ & $\mu \mathrm{g} / \mathrm{g}$ & $\mathrm{a}$ & $\mathrm{a}$ & $<0.5 b$ & 7.4 & 7.6 & $<0.5 b$ \\
\hline Urine & $\mu \mathrm{g} / \mathrm{g}$ & 15.9 & 6.9 & 57.8 & $\mathrm{a}$ & $\mathrm{a}$ & $\mathrm{a}$ \\
\hline Grass & $\mu \mathrm{g} / \mathrm{g}$ & 29.2 & 46.9 & $\mathrm{a}$ & & & \\
\hline
\end{tabular}

$\overline{{ }^{\mathrm{a}} \text { Not analyzed, }}{ }^{\mathrm{b}}$ Detection limit.

\section{DISCUSSION}

The diagnosis of toxicosis caused by MSMA was based on epidemiological, clinical, pathological, and toxicological findings analysed. Subacute disease was characterized by the evolution of the clinical conditions within a 20-day period, during which approximately $90 \%$ of the animals recovered from the toxicity (184/200); however, 16 animals died, mainly in the 10-day period. As previously observed, diarrhea and intense dehydration may have caused the deaths observed in the present study (Bertin et al. 2013). Except the cattle which extended the clinical condition, such the bovine $\mathrm{F}$, where severe lesion of tissue infarction certainly contributed to the death.

Excluding the samples from bovine F, As levels were above $0.5 \mu \mathrm{g} / \mathrm{g}$, value that is considered the reference threshold for the specie (Monies 1999). Several studies have shown a wide range of As tissue levels in bovines with signs of toxicosis, ranging from $0.5 \mu \mathrm{g} / \mathrm{g}$ to $800 \mu \mathrm{g} / \mathrm{g}$ (Neiger et al. 2004, Bertin et al. 2013). However, As levels may fall below $10 \mu \mathrm{g} / \mathrm{g}$ a few days after exposure, probably because of its rapid metabolism (about 48 hours in rats and mice) (Neiger et al. 2004, ATSDR 2015). This may explain the absence of As in tissue samples of bovine $\mathrm{F}$. The animals that died soon after contact with MSMA, on 4th and 6th day (bovines A and C, respectively), had high urinary As levels. Unfortunately, we could not detect the level of urinary arsenic in bovine F, due to lack of urine sample during necropsy. As levels above the toxic threshold were detected in the skeletal muscle of bovines D and E, therefore the meat of these animals would be unfit for consumption.

The observed gross and microscopic changes revealed that the animals that died in six and ten days (bovine C, D, $\mathrm{E}$ and F) had larger areas of infarction associated with vascular necrosis than bovines that died four days after MSMA exposure (A and $B$ ). The lesions observed in bovines $C, D$, $\mathrm{E}$ and $\mathrm{F}$ showed greater extent and were seen macroscopically as great areas of transmural infarction, whereas in bovines $A$ and $B$ the infarction was observed only microscopically. This may be associated with higher concentrations of arsenic detected in pasture on $6^{\text {th }}$ day, because these animals might have ingested a larger amount of the herbicide, as well being exposed for extended time in the contaminated pasture. Another aspect to be considered is the rapid clinical evolution to the death of the bovines exposed for 4 days. In these cases the time to establishment of necrotic lesions was shorter. The cattle of this study exhibited severe vascular damage in the digestive mucosa (6/6) which progressed to multifocal transmural infarction mainly in pre-stomachs $(4 / 6)$.

The vascular change is implicate as a factor that contributes to the degenerative and necrotic lesions caused by As (Osweiler 1996). However except in a study with equines, vascular necrosis is not mentioned in outbreaks of inorganic or organic arsenic poisoning (Dickinson 1972, Pace et al. 1997, Neiger et al. 2004, Valentine et al. 2007, Dantas et al. 2012, Bertin et al. 2013).

Similar lesions are described in human skin blood vessels after chronic exposure to high inorganic As doses in contaminated water, a condition called blackfoot disease (Yu 
et al. 2002). Blackfoot disease is characterized by changes in peripheral blood vessels, including thrombosis and the thickening and fibrinoid necrosis of the walls of subcutaneous arterioles, and may evolve into gangrene of the upper and lower limbs (Hughes 2002, Yu et al. 2002). A previous study described this type of lesion in the intestines of horses poisoned with inorganic $\mathrm{As}^{\mathrm{V}}$, and the authors suggested that necrotizing vasculitis may be the pathogenic mechanism behind necrosis of the mucosa (Pace et al. 1997).

Little is known about the mechanism through which As affects the endothelial cells of both small and large vessels. However, the element is known to have systemic effects on capillaries, including higher permeability as well as loss of contractility and dilation, which reduces blood pressure, thus inducing thrombosis (Bartík 1981, Osweiler 1996, Monies 1999). Additionally, endothelial cell membranes seem to be primarily affected by As when permeability and plasma exudation rise (Bartík 1981). It is possible that the loss of contractility results from the role that As plays in the generation of cellular oxidative energy, triggered mainly by the bonding of As to sulfhydryl enzymes (Hueza et al. 2008). Nevertheless, toxic and highly reactive trivalent As metabolic compounds, such as methylarsonic acid (MMA ${ }^{\text {III }}$ ) and dimethylarsonic acid (DMA ${ }^{\text {III)}}$ ), are also formed in the process, and these compounds have similar effects on tissue as those of As ${ }^{\mathrm{III}}$. These substances can be detected in the urine of humans chronically exposed to As. In vitro studies have shown that these forms are more toxic to tissue than arsenite and arsenate ions (ATSDR 2015).

Therefore, the lesions observed in toxicosis caused by pentavalent forms of As may also be caused by intermediate trivalent metabolites produced during biotransformation. Somehow this observation contradicts the notion that organic pentavalent arsenic compounds as MSMA are less toxic than the trivalent forms of the metalloid, as was previously believed (Hughes 2002).

The main differential diagnosis considered in the present study was enteritis caused by Salmonella sp. (Monies 1999). However, histology of the intestinal samples revealed that the lesions were not very significant. Additionally, the cases of ruminitis and ulcerative omasitis were not compatible with a diagnosis of salmonellosis. The high morbidity rate of the herd and the fast evolution to diarrhea were strong indicators of enteropathy associated with toxicosis. Nevertheless, it is probable that the subacute lesions caused by As may have induced secondary bacterial infections in the intestines. Secondary infection with Aspergillus sp. and zygomycetes was taken into consideration in the present study, particularly because of the instances of thrombosis and vasculitis observed mainly in the rumen and omasum, but there was no evidence of the presence of fungal structures by evaluation with PAS and GMS staining.

Recently, As was declared the most toxic heavy metal to skin (Mauldin \& Peters-Kennedy 2016). However, this status seems to be more specifically valid in the human medical context (Hughes 2002, Yu et al. 2002). Except for a chronic toxicosis recently described in sheep by Ashrafihelan et al. (2013), gastrointestinal changes, especially in the forestomachs, are the main clinical manifestation of
As toxicosis in cattle in consecutive expositions. Currently, the condition may be associated with accidental exposure to MSMA because, in most countries, including Brazil, this compound has been used in herbicide formulations due to the ban on inorganic As compounds.

\section{CONCLUSIONS}

The results of the present study suggest that organic As MSMA induced mostly multifocal ischemic necrosis of the mucosa in the forestomachs due to thrombosis secondary to fibrinoid necrosis of arteriole and capillary walls.

Organic As toxicosis has to be considered in the differential diagnosis of diseases characterized by acute or subacute ulcerative lesions, as well as infections causing vascular damage in the forestomachs of cattle.

Acknowledgements.- The authors are grateful to the Coordination for the Improvement of Higher Education Personnel (CAPES) for the scholarship provided to Maiara Aline Gonçalves.

Conflict of interest statement.- The authors have no competing interests.

\section{REFERENCES}

ATSDR 2015. Toxicological Profile for Arsenic. Department of Health and Human Services, Agency for Toxic Substances and Disease Registry, Atlanta. Available from <http://www.atsdr.cdc.gov/substances/toxsubstance.asp?toxid=3>

Ashrafihelan J., Amoli J.S., Alamdari M., Esfahani T.A., Mozafari M., Nourian A.R. \& Bahari A.A. 2013. Arsenic toxicosis in sheep: the first report from Iran. Interdiscip. Toxicol. 6(2):93-98.

Bartík M. 1981. Intoxication of animals by inorganic poisons, p.39-129. In: Bartík M. \& Piskač A. (Eds), Veterinary Toxicology. 7th ed. Elsevier, New York. 346p.

Bertin F.R., Baseler L.J., Wilson C.R., Kritchevsky J.E. \& Taylor S.D. 2013. Arsenic toxicosis in cattle: meta-analysis of 156 cases. J. Vet. Intern. Med. 27(4):977-981.

Dantas G.N., Santa Rosa B.P., Cagnini D.Q., Cavalcanti R.M., Chiacchio S.B., Gonçalves R.C., Riet-Correa F. \& Borges A.S. 2012. Intoxicação aguda por metano arsonato ácido monossódico em bovinos. Pesq. Vet. Bras. 32(12):1239-1245.

Dickinson J.0. 1972. Toxicity of the arsenical herbicide monosodium acid methanarsonate in cattle. Am. J. Vet. Res. 33(9):1889-1893.

Döbereiner J., Camargo W.V.A., Valente F.A.T., Alencar Filho R.A., Canella C.F.C. \& Tokarnia C.H. 1967. Perfuração do abomaso e da parede abdominal na intoxicação de bovinos por arsênio. Pesq. Agropec. Bras. 2(1):293-299.

Faires M.C. 2004. Inorganic arsenic toxicosis in a beef herd. Can. Vet. J. 45(4):329-331.

Hatch R.C. \& Funnell HS. 1969. Inorganic arsenic levels in tissues and ingesta of poisoned cattle: an eight-year survey. Can. Vet. J. 10(5):117120.

Hueza I.M., Sant'ana M.G. \& Palermo-Neto J. 2008. Toxicologia do chumbo, mercúrio, arsênio e de outros metais, p.641-663. In: Spinosa H.S., Górniak S.L. \& Palermo-Neto J. (Eds), Toxicologia Aplicada à Medicina Veterinária. Manole, São Paulo. 942p.

Hughes M.F. 2002. Arsenic toxicity and potential mechanisms of action. Toxicol. Lett. 133(1):1-16.

Mauldin E.A. \& Peters-Kennedy J. 2016. Integumentary system, p.509-736. In: Maxie M.G. (Ed.), Jubb, Kennedy, and Palmer's Pathology of Domestic Animals. 6th ed. Saunders Elsevier, Philadelphia. 2456p.

Monies B. 1999. Arsenic toxicosis in cattle. In Pract. 21(10):602-607.

Neiger R., Nelson N., Miskimins D., Caster J. \& Caster L. 2004. Bovine arsenic toxicosis. J. Vet. Diagn. Invest. 16(5):436-438. 
Nelson H.A., Crane M.R. \& Tomson K. 1971. Inorganic arsenic poisoning in pastured feeder lambs. J. Am. Vet. Med. Assoc. 158(11):1943-1945.

Osweiler G.D. 1996. Metals and minerals, p.182-185. In: Ibid. (Ed.), Toxicology. Williams and Wilkins, Pennsylvania. 526p.

Pace L.W., Turnquist S.E., Casteel S.W., Johnson P.J. \& Frankeny R.L. 1997. Acute arsenic toxicosis in five horses. Vet. Pathol. 34(2):160-164.

Reviere J.E., Boosinger T.R. \& Everson R.J. 1981. Inorganic arsenic toxicosis in cattle. Mod. Vet. Pract. 62(3):313-314.

Serodio P.S. 2014. Identificação do dano causado pelo uso agrícola do ingrediente ativo metano-arseniato ácido monossódico (MSMA): uma reavaliação toxicológica. Dissertação de Mestrado em Vigilância Sanitária, Instituto Nacional de Controle de Qualidade em Saúde, Fundação Oswaldo Cruz, Rio de Janeiro. 61p.

Valentine B.A., Rumbeiha W.K., Hensley T.S. \& Halse R.R. 2007. Arsenic and metaldehyde toxicosis in a beef herd. J. Vet. Diagn. Invest. 19(2):212215.

Vorhies M.W., Sleight S.D. \& Whitehair C.K. 1969. Toxicity of arsanilic acid in swine as influenced by water intake. Cornell Vet. 59(1):3-9.

Yu H., Lee C. \& Chen G. 2002. Peripheral vascular diseases resulting from chronic arsenical toxicosis. J. Dermatol. 29(3):123-130. 